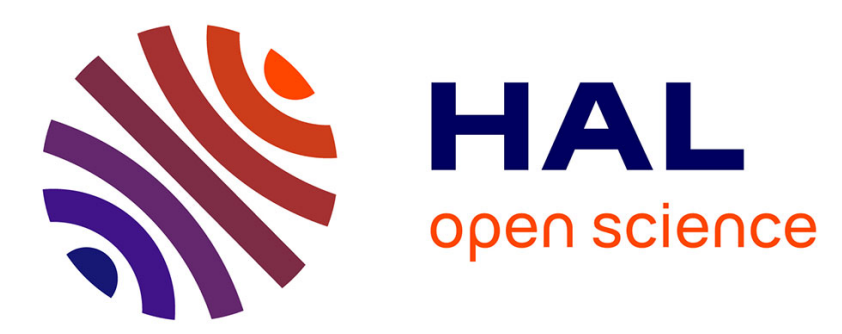

\title{
François-Paul de Lisola and English Opposition to Louis XIV
}

\author{
Charles-Edouard Levillain, Mark Goldie
}

\section{To cite this version:}

Charles-Edouard Levillain, Mark Goldie. François-Paul de Lisola and English Opposition to Louis XIV. Historical Journal, 2020, 63 (3), pp.559-580. 10.1017/S0018246X19000025 . hal-02920175

\section{HAL Id: hal-02920175 \\ https://hal.science/hal-02920175}

Submitted on 24 Aug 2020

HAL is a multi-disciplinary open access archive for the deposit and dissemination of scientific research documents, whether they are published or not. The documents may come from teaching and research institutions in France or abroad, or from public or private research centers.
L'archive ouverte pluridisciplinaire HAL, est destinée au dépôt et à la diffusion de documents scientifiques de niveau recherche, publiés ou non, émanant des établissements d'enseignement et de recherche français ou étrangers, des laboratoires publics ou privés. 


\title{
FRANÇOIS-PAUL DE LISOLA AND ENGLISH OPPOSITION TO LOUIS XIV*
}

\author{
MARK GOLDIE \\ Churchill College, University of Cambridge
}

A N D

CHARLES-ÉDOUARD LEVILLAIN

University of Paris

\begin{abstract}
Between the Restoration in I66o and the Revolution in I 688 the English public abandoned its century-long animus against Spain and began to identify France as its chief enemy. Historians often hold that the most significant intervention in shifting the balance of public opinion was the Dutch-inspired pamphlet, England's appeal from the private cabal at Whitehall (1673), written by the Huguenot Pierre du Moulin. It is argued here that an immensely influential earlier intervention was made by François-Paul de Lisola, in his Buckler of state and justice (I 667), which, at a critical juncture, presented a rhetorically powerful body of arguments about the nature of the European state system. A Catholic in the service of the Habsburg emperor, who spent nearly two years in England in I666-8, Lisola was an accomplished and versatile diplomat and publicist. This article interweaves diplomatic history with the history of geopolitical argument, tracing paths which led to Europe's Grand Alliance against Louis XIV.
\end{abstract}

During the seventeenth century, the anxieties of the English concerning their place in Europe were transformed, fear of Spain giving way to fear of France. Both fears were underwritten by a profound apprehension about the prospects for the survival of the Protestant religion in the face of Catholicism's most powerful monarchies, which were identified as aspiring to 'universal monarchy'. Yet both fears also came to be recalibrated in a new language of 'reason of state' and the 'interest of England', yielding an imperative to preserve a European 'balance of power'. But when exactly did fear of France replace fear of Spain? The Armada's shadow was lengthy and Spanish decline

Churchill College, Cambridge, CBз oDS magIo Io@cam.ac.uk

Université de Paris, 75 Io3 Paris charles-edouard.levillain@univ-paris-diderot.fr

* The authors wish to thank Gabriel Glickman and Jacqueline Rose, as well as the journal's anonymous referees, for advice on earlier drafts. 
was only slowly recognized. At some point between Oliver Cromwell's war against Spain in 1655 and William III's against France in 1689 , the balance of English foreign policy and public sentiment decisively shifted. Cromwell's war ended a century of intermittent conflict with Spain, William's inaugurated the 'Second Hundred Years War' with France. During the intervening years, foreign policy was turbulent, complicated by warfare with a third enemy, the Dutch Republic, but marked particularly by the partiality of Charles II and James II towards Louis XIV. If the Triple Alliance against France of 1668 temporarily signalled a new departure, the Second and Third Anglo-Dutch Wars $\left(1665^{-7}, 1672-4\right)$, the Treaty of Dover (1670), and the Treaty of Nijmegen (1678) marked open or clandestine alliance with France, or, at least, benign neutrality towards her. As for wider public sentiment, it is probably true to say that anti-French opinion gained the upper hand by 1673 . The case made here is that a tract published in 1667 was a powerfully persuasive stimulant to this reorientation. The paradox is that its author was a Burgundian Catholic in the service of the Habsburgs.

Habsburg opposition to France was to be expected, but Habsburg influence on the framing of Restoration English foreign policy remains overlooked in the historiography, the assumption being that the pro-Habsburg stance of English geopolitics only became entrenched in the eighteenth century. ${ }^{1}$ That the story of this shift commenced with François-Paul de Lisola in the 1660 s invites us to recognize earlier Habsburg diplomacy in the formation of an Anglo-Dutch alliance against France. This article will offer an analysis of Lisola's Buckler of state and justice but it will also bring to light new archival findings concerning the diplomatic role played by Lisola during his London residence between 1666 and 1668, at a moment when Charles II's foreign policy was caught in an uneasy balance between an anti-French and antiDutch strategy.

The storming of the Spanish Netherlands by French troops in the spring of 1667 awoke Europe to the expansionary ambitions of Louis XIV, a monarch who had embarked on his personal rule after the death of Mazarin in 1661. It seemed that he wished to emulate the pan-European imperium craved by Philip II of Spain in the sixteenth century. Led by Marshall Turenne, the French invasion of the Low Countries proved a huge success, leaving foreign observers in a state of shock. The smooth progress of Louis's army into Flanders was compared to 'a ballet on foot and on horse' by Adriaen van der

${ }^{1}$ For the eighteenth century, see Brendan Simms, Three victories and a defeat: the rise and fall of the first British Empire, I $7 I_{4}-I 783$ (London, 2007); Hamish Scott, The birth of a great power system, I 740-I 8 I 5 (London, 2005); Jeremy Black, A system of ambition?: British foreign policy, I660-I 793 (Harlow, 1991). 
Goes, a Catholic Dutchman resident in The Hague. ${ }^{2}$ Louis's 'ballet' led to the conquest of Armentières, Bergues, Tournai, Douai, and Lille. Advisers to the Spanish court were well aware that there was more at stake than the incorporation into French territory of a poorly defended buffer zone. In the words of José Arnolfini, an Hispano-Italian scholar with considerable influence at the court of Carlos II, Louis's aim was indeed 'to emulate the grandeur' of the Spanish monarchy. ${ }^{3}$

This War of Devolution, as it is called, cast upon Europe the first shadow of the problem of the Spanish Succession, which would embroil it in the wars of 1688-1713, concluded by the Treaty of Utrecht, which, whatever Louis XIV lost thereby, secured for the Bourbons the Spanish throne. The dynastic question was initially posed by the frailty of Philip IV, who belatedly produced a male heir, the sickly Carlos II who reigned from $166_{5}$, and whose unexpected survival postponed the crisis for four decades until his own childless death in 1700 . Meanwhile, Philip left two further problematic dynastic bequests. Of the two daughters by his first marriage, the elder, Maria Theresa, was queen of France, and the younger, Margaret Theresa, was empress of Austria, marriage alliances which offered prospects of Spain falling either to France or to a reunified Habsburg monarchy. Ostensibly, the French claim had been laid to rest at the moment of Maria Theresa's marriage to Louis. In 1659, the Treaty of the Pyrenees between France and Spain had been sealed by their betrothal, on condition that she, the infanta, renounce her claim to the Spanish throne. The War of Devolution was a rejection of that undertaking.

Among the many reactions across Europe to Louis's military offensive, one in particular calls for attention. A lawyer by the name of Nicolas Mahuet was residing in Brussels, the capital of the Spanish Netherlands. Mahuet originally came from Franche-Comté, also a Spanish province, which in theory enjoyed the protection of the Holy Roman Emperor Leopold I, Carlos II's Habsburg cousin, as part of the Circle of Burgundy. The province's fate was bound up with those of Spain's more northerly provinces of Flanders and Brabant. Mahuet wrote a letter bemoaning the sudden loss of Tournai, a stronghold that had capitulated within a few hours. He realized that military assistance from the emperor would not materialize, the imperial court taking a calculated non-committal attitude to French aggression. 'Divine intervention' might perhaps halt 'Louis's unjust invasion', but Mahuet's greatest hope rested on the shoulders of a compatriot from Franche-Comté, François-Paul de Lisola: 'If we manage to outlive the present sacrifice, it will partly be thanks to the care and remonstrances of the

${ }^{2}$ Adriaen van der Goes to his brother, 19 July 1667: C. J. Gonnet, ed., Briefwisseling tusschen de gebroeders Van der Goes (2 vols., Amsterdam, 1899), I, p. 328 . For a contemporary account of the war, see Pierre Dalicourt, A relation of the French king's late expedition into the Spanish Netherlands (London, 1669).

3 José Arnolfini de Illescas, Una mirada a la Monarquía española de finales del reinado de Felipe IV, ed. Cristina Hermosa Espeso (Valladolid, 2010), p. 10o. We have anglicized monarchs' names, except for Carlos II, to avoid confusion with Charles II. 
baron of Lisola, ... Never has a patriot shown greater zeal.' 4 Who was this 'patriot' upon whom Mahuet relied as the potential saviour of the Spanish Netherlands? As one of the early inspirers of anti-Ludovician resistance in Europe, Lisola proved a remarkably productive anti-French pamphleteer whose pen made way for the swords of William III, Marlborough, and Prince Eugene of Savoy. In the words of Winston Churchill, Lisola 'devoted his whole life to this purpose of curbing the overweening power of France'.5 Lisola did so by a mix of shuttle diplomacy and intense anti-French polemic and it is this particular combination that distinguished him from his fellow negotiators and pamphleteers. Described as one of the finest diplomats of his time, Lisola was denied official ambassadorial status by the imperial court, fulfilling nonetheless an essential peripatetic role as the emperor's resident in several European capitals: London, Madrid, Berlin, The Hague, Warsaw, and Danzig. His first posting took him to London during the opening years of the English Civil War, where he returned in 1666-8, precisely at the time of Louis's aggression in Flanders.

A negotiator lacking formal ambassadorial status, as a pamphleteer Lisola suffered a similar fate. Only a small number of the tracts he wrote after 1667 can definitely be attributed to him, covering his authorial reputation with a mantle of ambiguity. Notable exceptions include the Bouclier d'état et de justice (The buckler of state and justice), which established his fame, and La sauce au Verjus (1674), published in the year of his death. ${ }^{6}$ Yet these were enough to ensure a remarkable contemporary literary fame, although he has received little scholarly attention outside the German-speaking world. So popular, according to Pierre Bayle, was the Buckler, that many 'libel makers' fraudulently assumed Lisola's name.7 It was indeed in the commercial interest of publishers to excerpt Lisola and sell Buckler-like pamphlets. Hence the allegation, in 1673 , that the Buckler had 'fathered many supposed children' across Europe and had become the 'Bible' of anti-Ludovician opposition. ${ }^{8}$

The existing literature on Lisola comes predominantly from Austria and Germany. It is no accident that the rediscovery of Lisola in German scholarship

4 Mahuet to the representatives of the Three Estates of Franche-Comté, 25 June 1667: Besançon, Archives départementales du Doubs, C.277, Fonds de l'Intendance, unfoliated.

5 Churchill Archives Centre, Cambridge: CHAR 8/429, fo. 19. Churchill studied this period intensively, in preparation for his multi-volume life of his ancestor, Marlborough, written in the shadow of the rise of Hitler.

${ }^{6}$ François-Paul de Lisola, Bouclier d'état et de justice, contre le dessein manifestement découvert de la monarchie universelle, sous le vain prétexte des prétensions de la reine de France (Brussels, 1667); English translation: The buckler of state and justice (London, 1667); La sauce au Verjus (Strasburg, 1674).

7 Bayle to Minutoli, 1 May 1675 , no. 89, http://bayle-correspondance.univ-st-etienne.fr/, p. 8. For Bayle's admiration, see Dictionnaire historique et critique (15 vols., Geneva, 1969), Ix, 'Lisola', at p. 283; first edition published in Amsterdam in 1697.

${ }^{8}$ The Hague, Koninklijke Bibliotheek, Kn.10647: Le dénouement des intrigues du temps (Brussels, 1673), p. 83 . 
coincided with the aftermath of Bismarck's triumph in the Franco-Prussian War of 1870 . The story of Lisola's anti-French crusade was taken up as part of the dynamic of Germany's search for national unity. However hard Lisola had tried to embrace a pan-European posture by describing himself as a 'citizen of the world', there was little he could do, 200 years later, to prevent Julius Grossmann presenting him as the harbinger of a balance of power wherein France would bow to Germany. 9 German historians have always been drawn to both facets of Lisola's career: diplomat and pamphleteer. Where the English and Dutch naturally tend to celebrate William III as architect of the Grand Alliance, relegating Lisola to a footnote, the Prussian historian Johannes Haller gave pride of place to Lisola, describing him as the 'only one' who had 'lucidly envisioned' the true 'designs of France'. ${ }^{10}$ Lisola could rightly be seen, from this particular angle, as a 'statesman' and the Buckler as an 'epoch-making' tract, a watershed in political discourse. ${ }^{11}$ Haller's encomium was brief and was soon surpassed by Alfred Pribram's monumental biography of 1894 , still a standard work. ${ }^{12}$ Pribram confessed a profound admiration for the Buckler, a tract 'that spoke to the heart' and not just the minds of Louis's opponents. ${ }^{13}$ Where Pribram rightly insisted on Lisola's crucial role in creating the Triple Alliance of 1668 between England, Sweden, and the Dutch, ${ }^{14}$ most English and Dutch historians see it as an Anglo-Dutch venture spearheaded by Sir William Temple and Grand Pensionary John de Witt. ${ }^{15}$ As for the Buckler, historians of political thought mention it in passing. ${ }^{16}$ In modern British scholarship, it has been overshadowed by the claim that the principal polemical effort to tilt England away from anti-Dutch and towards anti-French feeling was England's appeal from the private cabal at Whitehall (1673), a Dutch-sponsored pamphlet penned, in all

9 Lisola, Buckler, p. 276; Julius Grossmann, ed., Der kaiserliche Gesandte Franz von Lisola im Haag I672-I673, Archiv für österreichische Geschichte, LI (Vienna, 1873), at p. 81 .

${ }^{10}$ Johannes Haller, 'Franz von Lisola, ein österreichicher Staatsman des 17. Jahrhunderts',

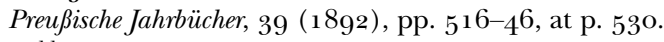

11 Ibid., pp. 532-3.

12 A. F. Pribram, Franz Paul Freiherr von Lisola $\left(16{ }_{1} 3^{-1} 6_{74}\right)$ und die Politik seiner Zeit (Leipzig, 1894). But see, more recently, Markus Baumanns, Das publizistische Werk des kaiserlichen Diplomaten Franz Paul Freiherr von Lisola (1613-1674): Ein Beitrag zum Verhältnis von Absolutistischem Staat, Öffentlichkeit und Mächtepolitik in der frühen Neuzeit (Berlin, 1994). Baumanns is the best existing study on the question of Lisola attributions. The end of the volume includes a reasonably certain list of Lisola's authentic publications.

13 Pribram, Lisola, p. $35^{6 .}$

14 Ibid., ch. 17.

${ }_{15}$ Herbert Rowen, John de Witt, Grand Pensionary of Holland (I625-1672) (Princeton, NJ, 1978), ch. 33; K. H. D. Haley, An English diplomat in the Low Countries: Sir William Temple and John de Witt, I665-1672 (Oxford, 1986).

${ }^{16}$ John Robertson, 'Empire and union: two concepts of the early modern European order', in idem, ed., A union for empire: political thought of the Union of I 707 (Cambridge, 1995), pp. 3-36, at p. 21; Peter Schröder, Trust in early modern international political thought, I598-I7I3 (Cambridge, 2017), pp. 143, 167-9. 
probability, by the Huguenot Pierre du Moulin, although the impact of that too is undeniable. ${ }^{17}$

Lisola's complex itinerary does not help, but the fact that he spent four years in The Hague as the emperor's resident $(1669-73)$ has not prevented Dutch historians from generally ignoring him. ${ }^{18}$ Religion is one reason. Lisola was a committed Catholic, 'an adopted child of the Society of Jesus', as he styled himself, ${ }^{19}$ at a time when anti-Catholic feeling ran high in the Dutch Republic. Keeping Lisola out makes it easier to colour the Triple Alliance as a Protestant league against Louis. It served a heightened confessionalization of anti-Ludovician policy. Another factor, at least from the English perspective, might be the remoteness of the imperial connection until the era of William III. Lisola's insistence that Emperor Leopold I should join the Triple Alliance failed to catch the attention of Charles II's ministers. Even Henry Bennet, earl of Arlington, the staunchest advocate of a Stuart-Habsburg bond, remained aloof, pleading that England and the emperor's Danubian lands were too far apart to be welded into a common league. ${ }^{20}$ For all his influence, Lisola's imperial loyalties marginalized him.

Lisola's role has thus been played down in recent writings on English foreign policy because the alliance with the Habsburg powers is routinely seen as a later by-product of the Anglo-Dutch alliance. ${ }^{21}$ Putting Spain and Austria at the forefront will illuminate the Habsburg dimension. We turn first to examine the nature of Lisola's contacts with the world of Restoration politics during the years of his second London residence; and then to consider the extent of the intellectual influence exerted by The buckler of state on Restoration political culture.

${ }^{17}$ K. H. D. Haley, William of Orange and the English opposition, $1672-1674$ (Oxford, 1953); Steven Pincus, 'From butterboxes to wooden shoes: the shift in English popular sentiment from anti-Dutch to anti-French in the 1670s', Historical Journal, 38 (1995), pp. 333-61. See also the Oxford dictionary of national biography article on Pieter du Moulin.

${ }^{18}$ Recent exceptions include: David Onnekink, Reinterpreting the Dutch forty years' war, ${ }^{16} 7^{2-}$ $I_{713}$ (London, 2016), ch. 3; Marianne Klerk, 'Reason of state and predatory monarchy in the Dutch Republic, 1638-1675' (Ph.D. thesis, Rotterdam, 2015), pp. 112-30; Jasper van der Steen, Memory wars in the Low Countries, I 566-I 700 (Leiden, 2015), pp. 233-5; idem, 'The political rediscovery of the Dutch Revolt in the seventeenth-century Habsburg Netherlands', Early Modern Low Countries, 1 (2017), at pp. 78-86.

19 Lisola to the father general of Jesuits, 17 Oct. 1670 : Romeinsche bronnen voor den kerkelijken toestand der Nederlanden onder der apostolische vicarissen, I592-I727, ed. R. R. Post (2 vols., The Hague, 1941), II, p. 557 .

${ }^{20}$ Arlington to Lisola, 20 Jan. 1671 (OS): British Library (BL): Add. MS $35^{125}$, fo. 236.

21 Steven Pincus, I 688: the first modern revolution (New Haven, CT, 2009), ch. 11; Tony Claydon, Europe and the making of England, I660-I76o (Cambridge, 2007), pp. 132-52. For a recent survey, see Gabriel Glickman, 'Conflicting versions: foreign affairs in domestic debate, 166o-1689', in William Mulligan and Brendan Simms, eds., The primacy of foreign policy in British history, I 660-2000 (Basingstoke, 2010). 
Before arriving in London in 1666, Lisola had engaged in a year-long diplomatic mission in Madrid, where he had left no stone unturned to thwart the influence of a powerful pro-French faction. ${ }^{22}$ These were critical years in Spain: Philip IV died in September $166_{5}$, leaving his ailing son Carlos in the hands of a faction-ridden regency led by his mother Queen Mariana, sister of Emperor Leopold. War with Portugal, begun in 1640, still raged. Owing to financial exhaustion, the Spanish Netherlands could not be properly defended, and hence were open to French attack. ${ }^{23}$ It was during this period in Madrid, when Lisola worked closely with Leopold's official ambassador Eusebius Pötting, that the French crown asserted its 'right of devolution', articulated in Antoine Aubery's Traité des droits de la reine (1666), a legal-political treatise published in defence of Maria Theresa's continuing rights over the Spanish Netherlands, notwithstanding her renunciation of them in the Treaty of the Pyrenees.

Before turning to the legal discourse surrounding devolution, something needs to be said about the Spanish context of ${ }_{1665}-6$ and Lisola's English contacts after his move to London. An unnoticed aspect of Lisola's Madrid residence is a manuscript tract written to rehearse the arguments that he would so successfully put forward in the Buckler in 1667. Drafted in September 1666, the tract posited one of the guiding principles of Lisola's geopolitical thought, namely the absolute priority of the defence of Flanders: an 'outer defence wall' (antemural), as he called it, guarding the Spanish Netherlands from the 'great power of France'. Giving up Flanders would result in severing a limb from the Spanish monarchy's 'main body'. Peace with Portugal was urgently required to reorientate Spain's diminishing military and financial resources towards its northern province. A 'true Spaniard', according to Lisola, could only revile 'the name of French'. ${ }^{24}$

The manuscript tract raised the issue of an alliance with England. Lisola bluntly posed the question: could Spain be expected to ally with the English 'heretics', in contradiction of her 'ancient maxims'? There was a precedent in Charles V's joining hands with Henry VIII against Francis I. There was no reason, according to Lisola, why this pattern should not be repeated if France was to be thwarted in its 'ambition of universal monarchy'. ${ }^{25}$ By arguing for a pro-English alliance against France, Lisola ran up against a powerful current

${ }^{22}$ Pribram, Lisola, ch. 13. On the factiousness of the Spanish court in the 1660 , see R. A. Stradling, 'A Spanish statesman of appeasement: Medina de las Torres and Spanish policy, 1639-1670', Historical Journal, 19 (1976), pp. 1-31.

${ }_{23}$ Castel-Rodrigo to Philip IV, 22 July $166_{5}$ : Brussels, Archives Générales du royaume (AGR, T 100/279, Secrétairerie d'état et de guerre, fo. 96 .

24 'Baron de Lisola sobre la paz de Portugal y liga con Francia. Antidoto contro el veneno de un papel che dijen se presento al Rey christianissimo por un ministro francés', 2o Sept. 1666: BL, Add. MS 14001, fos. 134-5, 146, 159 .

25 Lisola, 'Sobre la paz', fo. 159 . 
at the Spanish court that persisted in extolling the Catholicity of the monarchy, claiming that confessional allegiance was the best reason of state. On this point, the influential scholar-courtier Arnolfini fundamentally disagreed with Lisola, describing the English, in his 'Discurso sobre si conviene más a España la liga con Inglaterra o Francia', as Spain's 'hereditary enemy'. That Spain should shun England was a matter of 'honour', not least because it was but a minor monarchy. ${ }^{26}$ Hence, Arnolfini's disapproval of Richelieu's and Mazarin's inter-confessional approach to coalition-making in the 1630 ond 1640 os. The two great Catholic monarchies of Europe, Spain and France, needed to subsume whatever disagreements they had under a shared religious understanding. Arnolfini's Counter-Reformation confessionalism stood within the long shadow of the Armada, and the call of divine providence.

Although Lisola's manuscript tract remained unpublished, the battle of words and ideas initiated against Arnolfini resonated far beyond Madrid, catching the attention of Sir William Temple, who had been sent to Brussels on his first embassy. Temple and Lisola met in Brussels when the latter was making his way to London. Temple spoke highly of Lisola, describing him as 'an honest man' and 'an equal partner in business' (par negotiis), belying the negative image of Lisola conveyed by Charles II's envoys in Paris. ${ }^{27}$ Lisola promised to send Temple a copy of Arnolfini's 'Discurso'. Temple thanked Lisola, playfully expressing his eagerness to read a pamphlet that sounded more exciting than both Cervantès and the poet Francisco de Quevedo. ${ }^{28}$ It is apparent in their further correspondence that Lisola provided Temple with manuscripts, books, and reflections. He was an intellectual with a special talent for the dissemination of ideas through both scribal and print media, and a signal example of the type of diplomat highlighted by recent scholarship that has rightly insisted on the importance of the intercourse of books in diplomacy. ${ }^{29}$

Upon settling in London in autumn 1666, Lisola found himself, as in Madrid, second fiddle to an officially appointed ambassador, though not in fact the emperor's. Count Molina, the representative of the Spanish crown, acted in practice on behalf of both the Spanish and German branches of the Habsburgs. The emperor was convinced that Lisola wielded far more influence than his Spanish colleague: 'Without Lisola, Molina exerts only limited powers, which people find paradoxical'. $3^{\circ}$ Leopold's comment needs

\footnotetext{
${ }^{26}$ José Arnolfini, 'Discurso': BL, Harleian MS 4520, fos. $117,119$.

${ }_{27}$ Temple to Arlington, 2 Nov. 1666: The National Archives, Kew (TNA), SP 77/35, fo. 1 24; Anon. to Arlington, 20 Jan. 1667: TNA, SP $78 / 123$, fo. 11.

${ }_{28}$ Temple to Arlington, 2 Nov. 1666: TNA, SP 77/35, fo. 124.

${ }^{29}$ Joanna Craigwood, 'Diplomats and international book exchange', in Ann Thomson, Simon Burrows, and Edmond Dziembowski, eds., Cultural transfers: France and Britain in the long eighteenth century (Oxford, 2010), pp. 57-69; Claude Hauser, Thomas Loué, J.-Y. Mollié, and François Valloton, eds., La diplomatie par le livre: réseaux et circulation internationale de l'imprimé de I 880 à nos jours (Paris, 2011).

$3^{\circ}$ Leopold to Pötting, 24 Sept. 1667: Privatbriefe Kaiser Leopold I an den Grafen F. E. Pötting, I662-I673, ed. A. F. Pribram (2 vols., Vienna, 1903), I, p. 321.
} 
to be qualified, the surviving sources showing that Molina had not waited for Lisola to make a strong case in favour of Flanders. In $166_{5}-6$, Molina had resided at New College, Oxford, to escape the Plague and Great Fire of London, establishing fruitful contacts with the warden and fellows who hosted him. The right of devolution was one of the subjects Molina discussed with his hosts who, at this stage, must have had little other source of information to satisfy their curiosity. Several tracts relating to the right of devolution were donated by Molina to the college during and after his residence, bringing to Oxford the most up-to-date literature on the subject and alerting Oxford scholars to the complexity of devolution debates. These tracts included Pierre Stockman's Tractatus de jure devolutionis (Brussels, 1666) and Lisola's Buckler of state, with its appended Free conference touching the present state of England both at home and abroad: in order to the designs of France (1668). In an unpublished investigation, David Ogg found that in acknowledging the gifts, the Warden [Anthony Woodward] assured the ambassador that all New College men were convinced of the justice of the Spanish case against French aggressions in the Low Countries'. $3^{1}$ Molina's lobbying had thus not been without effect prior to Lisola's arrival in London.

Owing to the peripatetic nature of his career, Lisola remained in the best position to affirm Habsburg solidarity in the face of French aggression and overcome Spanish-German intra-dynastic friction and conflicting foreign policy agendas. His arrival in London immediately became a matter of concern in Paris. Louis XIV responded by sending Henri Massue, marquis de Ruvigny, to London: not a Catholic, but a Huguenot who was related to the earl of Southampton, Charles II's lord treasurer. $3^{2}$

It took little time for Ruvigny to assess the situation. Lisola had established fruitful contacts with a solid core of members of parliament.33 Hence, the French crown's generous flow of gifts and subsidies to shore up its own interests at the English court. Charles II was increasingly worried by French ambitions in the Spanish Netherlands but, as Lisola pointed out, 'the money dished out by French ministers' had power to sway the king's will and to help Ruvigny 'instil his venom'.34 The Second Anglo-Dutch War was still in progress but

$3^{1}$ New College, SCR/B/OGG. With thanks to Christopher Skelton-Foord, David Parrott, and Jennifer Thorp. Snippets of Molina's New College correspondence are kept under NCA 927. Ogg was a fellow of the college and author of a standard work on the reign of Charles II.

$3^{2}$ Marc Antonio Giustinian to Venice Senate, 1 Feb. 1667 (OS): Calendar of State Papers, Venetian, I666- I668 (CSPV), p. 125 .

33 Ruvigny to Lionne, 26 Sept. 1667 (OS), Paris, Ministère des affaires étrangères, correspondence politique: Angleterre, 89, fo. 99 .

34 Lisola to Leopold, 26 Sept. 1667 (OS): New Haven, Beinecke Library (TBL), GEN-MSS530, Harrach Papers, v, fo. 269. According to Spanish sources, Ruvigny's mission of 1667-8 cost the French crown 200,ooo livres tournois, amounting to some £16,ooo. Clarendon, Charles II's chancellor, was paid an annual fee of 50,ooo livres tournois, some $£_{4}$, ooo. Richard to Precipiano and Philippe, 7 Sept. 1667: AGR, I o74/614, Secrétairerie d'état allemande, fo. 107 . 
the French invasion of the Low Countries in May 1667 was bound to complicate any search for a bilateral agreement, shifting the focus towards the mightiest of all three military powers: France. Lisola's mission was to roll back Ruvigny's antiDutch lobbying and pave the way for a peace settlement between England and the Dutch, involving a reversal of alliances. 35 Only under such conditions would the Habsburgs be able to serve as the 'arbiters' of a wider peace. ${ }^{6}$

In London, Lisola liaised mainly with the earl of Arlington and George Villiers, second duke of Buckingham, describing them as 'friends and confidants of the House of Austria'.37 Habsburg attentions were extended to Sir Joseph Williamson, an Arlington protégé and future secretary of state, whom the Spanish crown showered with gifts for his contribution to the AngloSpanish commercial treaty of May 1667 and who, crucially, supervised the translation of the Bouclier into English. The name of the Scottish translator - an official from the Department of State - remains unknown but, according to Spanish sources, the handsome sum of $£_{5}$ o was paid for his work. $3^{8}$ Among Lisola's contacts at the English court, Williamson was certainly the most learned. A fine linguist and keen book collector with wide continental connections, Williamson also owned a Spanish version of the Buckler, a symptom of the circulation of Lisola's tract in several languages. 39 The French and English versions must have been the ones most widely read.

Lisola held a number of secret meetings with Arlington, Buckingham, and Molina to tune his strategy. It was taken for granted that the English court included a strong pro-French faction. Turning the tables on the French crown, however, was not enough to engage English sympathies for Habsburg concerns for the fate of Spanish Flanders. Like Arlington, Lisola appreciated the sense of physical distance between Vienna and London. Hence, an energetic anti-French propaganda campaign was envisaged: 'With the help of secret papers, we will seek, here [in London] as well as in the other provinces, to uncover the wily intentions of the French crown, instilling into people's minds everything that can contribute to the promotion of our cause'. $4^{\circ}$

Lisola's main enemy in England was Lord Chancellor Edward Hyde, earl of Clarendon, who had sold Dunkirk to France in 1662 and was soon to be blamed for the failure of the Anglo-Dutch War, particularly the catastrophic humiliation by the Dutch in their raid on the River Medway in June 1667 .

35 Lisola to Leopold, 26 Sept. 1667 (OS): Vienna, Haus-, Hof- under Staatsarchiv (HhstA), Staatenabteilung, Großbritannien, Diplomatische Korrespondenz, 9, fo. 24 .

$3^{6}$ Lisola to Anon., 21 Feb. 1667: Simancas, Archivo General, Estado 2382, unfoliated.

37 Lisola to Leopold, 12 Mar. 1668 (OS): TBL, GEN-MSS-530, Harrach papers, v, fo. 707.

$3^{8}$ 'Cuentas de embajadores y ministros en Inglaterra', 18 Oct. 1669: AGS, Estado 3972, unfoliated.

39 TNA, Williamson papers, SP 9/43, Broquel de Estado, p. 8. For a recent study of Williamson's continental networks, see Alexandre Tessier, Réseaux diplomatiques et République des Lettres: les correspondants de Sir Joseph Williamson (Paris, 2015).

$4^{\circ}$ Lisola to Leopold, 26 Sept. 1667: TBL, GEN-MSS-53o, Harrach papers, v, fo. 254 . 
Arlington urged the king to dismiss Clarendon while Buckingham orchestrated the campaign to have the fallen chancellor impeached. Behind the scenes, Lisola exhorted members of the emerging Country party to exact severe revenge. When the parliamentary campaign to impeach was tottering, he prompted MPs John Vaughan and Sir Robert Howard to add to the charge sheet that the chancellor had betrayed the king's secrets to France: a majority for impeachment ensued. $4^{1}$ Lisola's fear had been that Clarendon might goad Charles II into a formal alliance with Louis: 'If, to say the truth, the chancellor persists in favouring France, I fear he might not only ruin all our efforts, but push the king into an alliance with France. Should this happen, then parliament will be our sole refuge.' Lisola's hope was to convince Charles II that the security of Flanders should prevail over all other foreign policy concerns, for it was England's crucial 'barrier' and touched upon the 'honour' of the English crown. $4^{2}$ We see here an attempt to entrench what became a centuries-long conception of Flanders as England's crucial continental 'barrier'.

After the signing of the Treaty of Breda between England, France, and the Dutch in July 1667 , bringing a swift end to the war, parliament forced Charles II to disband the troops that had been levied during the war. So farreaching was Lisola's influence that the Venetian resident suspected him of having orchestrated a further move to have fresh troops ready to be shipped to Flanders. 43 Lisola was seeking to manoeuvre England into a strategy of limited continental commitment in the Low Countries, as had happened in the 1570 , when Spain, rather than France, had been English's main enemy, and Queen Elizabeth had helped give birth to an independent Dutch Republic.

\section{I I}

We are now in a position to examine more closely the substance of the Buckler. The main legal justification for Maria Theresa's 'right of devolution' had come from Aubery's Traité-A treatise of the rights of the Most Christian Queen to several states of the Spanish monarchy (1666), a tract sponsored by Louis XIV, which enjoyed a huge circulation in Europe and which Lisola now sought to refute. Aubery's tract was sent to the English court by Henry Jermyn, earl of St Albans, Charles II's ambassador in Paris. 44

$4^{1}$ CSPV, 20 Sept. 1667 (OS), p. 184; BL, Egerton MS 2539, fos. 135-6; 'Vaughan, John', History of Parliament: the House of Commons, 166o-169o: www.historyofparliamentonline. org; Clayton Roberts, 'The impeachment of the earl of Clarendon', Cambridge Historical Journal, 13 (1957), pp. $13^{-14}$.

$4^{2}$ Lisola to Leopold, 2o Aug. 1667 (OS), HhstA, Staatenabteilung, Spanien, Diplomatische Korrespondenz, $5^{1 / 1}$, fos. $126-7$.

43 CSPV, 23 Aug. 1667 (OS), p. 180.

44 Dalicourt, A relation of the French king's late expedition, p. 5. St Albans to Arlington, 11 May 1667: TNA, SP 78/123, fo. 80. George Digby, earl of Bristol, a Catholic courtier, owned a copy of the pro-Aubery Dialogue au sujet des droits de l'actuelle reine de France (Dialogue on the rights of the present queen of France) (Paris, 1667): Bibliotheca Digbeiana (London, 168o), p. 112. 
Aubery made three claims. The first was that Maria Theresa's renunciation of Spanish claims, in the Treaty of the Pyrenees, was void, because it was conditional upon a dowry that had never been paid. The second, more fundamental, and drawing upon the legal tradition of Bodinian sovereignty, was that any renunciation by a monarch, or heir to a monarchy, of the essential rights of the crown was ipso facto null and void: sovereigns could not alienate the foundations of their sovereignty, so that entitlements to territories arising from dynastic matches could not be set aside. The third was that, by the laws of Brabant and most other provinces of the Spanish Netherlands (Flanders, Luxembourg, Burgundy), the right of inheritance, in the event of there being heirs by a second marriage, devolved upon the heirs of the first - the eponymous 'devolution'. Hence, Maria Theresa, queen of France, and not her half-brother Carlos II, was rightful heir to Brabant and its neighbouring duchies.

There were several published responses to Aubery's Traité, including the Tractatus de jure devolutionis by Stockmans, a Flemish lawyer in the service of the Spanish crown, and La verità vendicata dai sofismi di Francia (Vienna, 1667) by Domenico Federici, an Italian priest serving the imperial court in Vienna, 45 but the most powerful and influential was Lisola's Bouclier, the chief among some twenty tracts he issued down to his death. The Bouclier, published initially at Brussels in French, had at least eleven editions in six languages between 1667 and $1702.4^{6}$ The treatise crowned Lisola's intervention in English debate, for within one month it was translated as The buckler of state and justice against the design manifestly discovered of the universal monarchy, under the vain pretext of the queen of France her pretensions. This octavo of $33^{1}$ pages was printed 'for Richard Royston, bookseller to his most excellent majesty', and carried an imprimatur signed by Joseph Williamson on behalf of the earl of Arlington, dated 'Whitehall, 19 September 1667 '. Evidently it had the approval of powerful anti-French elements within the government.

In the aftermath of the disastrous Second Anglo-Dutch War, the tract spearheaded attempts decisively to reorientate English foreign policy in an antiFrench direction. The Triple Alliance was the first fruit of that new policy, and it succeeded in frustrating Louis's War of Devolution, forcing him to compromise in a peace settlement at Aix-la-Chapelle (1668). Yet, in the medium term, Lisola and the English anti-French party failed utterly, because before long Charles signed the Treaty of Dover (1670) and embarked on the Third Anglo-Dutch War (1672-4), once more in alliance with Louis. Worse still, for Lisola personally, the double French invasions of his native Franche-Comté in 1668 and 1674 left him distraught - he died in the latter year.47 In 1673, as

45 See Michele Tagliabracci, 'L'aventurosa vita di Domenico Federici', Nuovi Studi Fanesi, $24-5(2010-11)$, pp. 27-103.

$4^{6}$ French (Brussels, 1667, 1668; n.p., 1701), Spanish (Madrid, 1667; Brussels, 1667), Italian (Madrid, 1667), Dutch (Amsterdam, 1667; ?1702), German (Frankfurt, 1667), English (London, 1667, 1673, 1677).

${ }_{47}$ Lisola to Precipiano and Philippe, 24 Feb. 1668: AGR, I o74/614, fo. 294. 
part of the paper assault on Charles's pursuit of another Anglo-Dutch war, the Buckler was reissued with a new title page. There was now added to it, with a separate title page, a seventy-six-page essay called A free conference touching the present state of England both at home and abroad: in order to the designs of France. $4^{8}$ This carried a licence dated 21 January 1668, so was not new. A further English edition of the Buckler appeared in 1677 , and another in French in 1701, on the eve of the War of the Spanish Succession. 49 The Free conference reappeared in 1673 and 1678 .

The Buckler was not a tract for the faint-hearted or impatient. Carrying little contextual explanation to aid the English reader, it is dense, submerging quickly into diplomatic and legal intricacies, and involving lengthy disquisitions on such matters as the history and law of princely succession in Brabant and Burgundy. It was in need of a combative précis. The supplementary Free conference, composed in the fashionable genre of an imaginary conversation, was better calculated to the taste of the London coffee houses. Had the Buckler been shorter and shorn of circumstantial detail, its remarkable array of arguments, and trenchant aperçus, would have been more resounding, for it takes up several emerging topoi of foreign policy debate, entangling the translatio imperii tradition (the historical transmission of ancient claims to universal monarchy) with new analyses of international trade and the 'balance of power', together with a clarion call for the 'liberty of Europe'. Lisola proclaimed: 'we are here to decide the fortune of Europe, and to pronounce the sentence either of its freedom or slavery'.$^{\circ}$ Yet, for all its intricacies, the Buckler captured immediate attention, a measure not least of the sophistication in foreign affairs of its English readership. Samuel Pepys got his wife to read it to him on the day of its publication and thought it 'very good and solid ... and doth give a very good account of the advantage of our league with Holland' $.5^{1}$

The elemental thrust of the Buckler is its allegation of a French ambition to achieve 'universal monarchy'. $5^{2}$ Lisola reminds readers of the French pretension that Germany belonged to her patrimony as the legacy of the Emperor Charlemagne, a belief that projected French power toward the Rhine and beyond. Emulation of the Habsburg Empire, he argues, is the growing canker

$4^{8}$ The imprint now: 'for Richard Royston, and are to be sold by Richard Chiswell'; the two items priced separately at $2 s 6 d$ and $1 s$, according to Chiswell's catalogue in William Cave, Primitive Christianity (London, 1675).

49 A single copy of the 1701 edition has been traced in the Bibliothèque Nationale, Paris: 8-OC-5O4 (G).

$5^{\circ}$ Lisola, Buckler, p. 275 .

$5^{1}$ Robert Latham and William Matthews, eds., The diary of Samuel Pepys ( 11 vols., 1971-83), Ix, p. 61 (10 Feb. 1668); C. S. Knighton, ed., Catalogue of the Pepys Library: census of printed books (Cambridge, 2004), no. 841 .

$5^{2}$ Within the history of political thought, the theme of 'universal monarchy' would need to place Lisola in relation to such authors as Francis Bacon, Christoph Besold, Giovanni Botero, Tommaso Campanella, the duc de Sully, and Andrew Fletcher. For England, see Steven Pincus, 'The English debate over universal monarchy', in Robertson, ed., Union for empire. 
in the heart of France and productive of 'all the misfortunes and troubles of Christendom'. He alludes to France's current interventions across Europe, in the Polish succession, and in seducing Sweden and Portugal. In the modern world, he argues, universal monarchy takes a novel form: the ambition to corral international trade. Assuming that overseas commerce was a zero-sum game, Lisola warns the English in particular of France's new aspiration to be 'absolute mistress of the trade'.53

The tract is an appeal to the nations to awaken to the fact that it was France and not Spain that was the source of Christendom's instabilities: all that was once feared in the age of Charles $\mathrm{V}$ and Philip II should now be feared of Louis XIV. 'Many have been mistaken by a false supposition, that the power and the designs of Spain were more to be apprehended than those of France.' Although himself a Habsburg courtier, Lisola concedes that Spain, though 'a large machine', is a lumbering one, which cannot 'move with the agility which is necessary to foreign enterprises'. France, however, has manufactures, commerce, and a ruler with a lust for glory. Trade is forbidden to its nobility, who must find outlet in warfare, while its people, burdened by heavy taxation, must be beguiled by the smoke of conquest. For such a strategy, look no further for evidence, he urges, than the duc de Rohan's Interest of princes and states $(1610) .54$

The more immediate locus of Lisola's argument concerns the terms of the Treaty of the Pyrenees. The Buckler attacks three productions by the French king's 'scribblers',55 Aubery included, and shows that Louis regarded the treaty as a sham, a playing for time. At length, Lisola demolishes French casuistry and affirms that the infanta's renunciation of Spanish claims was inviolable: she was of the age of consent; she was not under duress; monarchs and their heirs may legitimately abdicate their inheritances; her renunciation was undertaken as a consciously virtuous guarantee of peace; her marriage was essential to the peace of Europe; and the abnegation was intrinsic to the marriage. Lisola expatiates on the solemn obligations incurred by treaties and promises, which involve the trust that is the foundation of public right, civil society, and the amity of nations.

When Lisola turns to the second arm of French casuistry, the law of inheritance in Brabant, he shows - and the generality of contemporary Europe and modern commentary agrees with him - that it is simply false to elide the difference between the law of inheritance of property and the law of succession to crowns. The law of devolution did indeed apply to Brabantian land tenure but had no bearing on princely sovereignty over the province. Lisola goes on to explain and defend a Europe of multiple principalities and fragmented supremacies rather than one of unitary sovereign states (let alone universal

53 Lisola, Buckler, pp. $15,276$.

54 Ibid., pp. 278-80.

55 Ibid., sig. A8r. 
empires), a vision that came naturally to a citizen of the Holy Roman Empire. If the king of France were to become duke of Brabant it would not make him sovereign of Brabant, for Brabant was a subsidiary fief of the empire: a Bourbon inheritance of Brabant would not incorporate Brabant into the French state. Louis was wrong to regard all his titles (real and putative) as conferring perpetual incorporation of territories into the body of France: he had multiple monarchies across independent principalities and was not sovereign of a unitary state. Lisola stresses, furthermore, the irony that whereas France had a Salic law forbidding female monarchs, Louis was pursuing a claim to Brabant through his wife: in Spain there was no Salic law. $5^{6}$

In assailing Louis's meddling with the rights of fellow monarchs, Lisola plays upon the conceit that a monarch who subverts fellow monarchs is a kind of republican: Louis 'aims absolutely at the entire destruction of a monarchy which is the bulwark of all the rest'. He emphasizes French stealth and dissimulation, seeking to awaken readers to designs of war undertaken under the mask of peace, augmenting his theme with the authority of Grotius's $O$ f the laws of war and peace, book III, chs. 19-20, on keeping faith. Snidely, he remarks that the French Academy, the arbiter of the French language, had not yet 'called war by the name of peace'. He recites the broader tradition of just war theory from Aquinas and Ulpian onward: there can be no just war where disputes are resolvable by negotiation and an appeal to the law of nations. 57

Although writing as a citizen of the empire, Lisola also spoke to the interests of England. He warns England of the folly of being gulled by Louis into war against the Dutch. In French plans, 'A war must be raised between England and Holland, and prolonged by a thousand artifices, to give themselves elbow-room to invade the Low Countries, whilst these two great powers should be drowned in blood to their reciprocal ruin.' The Anglo-Dutch wars fatally weakened England, and left the way clear for French aggression in Flanders. $5^{8}$

The Buckler's supplementary essay, a Free conference, was, so its preface says, delayed until peace with the Dutch. It purports to record a discussion at a statesman's dinner table, and its source is evidently English, and not Lisola. It is altogether a more legible and less arcane polemic for its native audience. More robustly than a servant of the Habsburgs might assert, the essay contends that 'the monarchy of Spain is just upon the brink of falling to the ground'. By contrast, France has a novel and 'vast design', not least to engross 'the commerce of our navigation'. The tract harps especially upon trade, characteristic of that newly fashionable preoccupation of public discourse. England, moreover, is recalled to her supposedly historic task to serve as the "counterbalance, which time-out-of-mind hath held the scales even betwixt those two great

$5^{6}$ Ibid., pp. 73-92.

57 Ibid., pp. 19-20, 26.

$5^{8}$ Ibid., pp. 13 , 294. 
monarchies' of France and Spain. This balancing should be 'a fundamental maxim of [our] conduct'. If France is permitted to triumph over Spain, then she will ultimately also be master of England's destiny. 'Sitting neuters' would be disastrous, and preserving the Low Countries is the key.59

The Free conference is markedly expansionist in its fiscal-military programme for the English state. Not only must the navy be increased, but also England must have an army as well. Given that Lisola's purpose was to draw England into a continental commitment, the essay shrewdly disguises this by accenting a 'Blue Water' vision along the lines of the Grotian mare liberum tradition: naval supremacy is England's destiny, and the minimizing of a continental commitment is to be achieved via alliances that create a counterpoise among European powers. Allaying fears of tax burdens, the navy, it is said, can help pay for itself through 'prizes gotten at sea'. As for the feared bogey of a 'standing army', it can be avoided because it is the standing navy which is the best instrument of an island nation's military capability. A great navy will be the 'seminary of good and able fighting men', an army in reserve: the navy undergirds the potential for a continental commitment. Indeed, an expanded navy can also solve the desperate problem of unemployment and the expense of poor relief, by employing 'a great company of idle persons, which now, being without employment, are a burden on the public'.6o

Since, in principle, the doctrine of counterbalance dictates neither a proSpanish nor a pro-French stance, without due empirical weighing of the threat from each, and since recent policy had been so avidly pro-French, the Free conference goes out of its way, for the sake of rhetorical fair-mindedness, to canvass arguments for a pro-French line, before turning to refute them. It is conceded that Charles II's recent pro-French policy has the potential of sharing the spoils of war against the Dutch, of giving access to eviscerated Spanish colonies in the New World, and of availing England of the formidable police powers of France which could within 'a few hours' destroy 'all manner of revolutions' fostered by brigades of expatriate Puritan and republican rebels an allusion to the much-canvassed characterization of the Dutch Republic as home to a fifth column of Cromwellian exiles. ${ }^{61}$ Yet these arguments are intended to be a foil to the mounting indignation of the gathered interlocutors. A grave statesman is roused to rebuttal. France has 'no greater desire than to take the dominion of the sea from us, and the precedency in commerce'. England will be the dupe and 'hireling' and not the sharer in the spoils of war in the Low Countries. We have a new commercial treaty with Spain which is advantageous to our trade. It is agreed that 'our power and greatness doth principally consist in the matter of commerce', and accordingly it is vital that

59 A free conference touching the present state of England (London, 1673), pp. 8-9, 20, 32.

6 o Ibid., pp. $25^{-7}$.

61 See Steven Pincus, Protestantism and patriotism: ideologies and the making of English foreign policy, I650-I 688 (Cambridge, 1996), ch. 14. 
the French do not control the ports of the Low Countries. France is perfidious: its breach of the Treaty of the Pyrenees is insidious; it had proved no true friend to either Charles I or II in times of Stuart crisis, and had instead made a 'shameful treaty' with the usurper Cromwell. ${ }^{62}$ All in all, the Free conference can be described as a successful domestication of Lisola's Buckler.

\section{V}

For several years, Lisola would continue to warn the English about the consequences of the War of Devolution. With the coming of Louis's guerre de Hollande (1672-8), the arguments of the Buckler appeared to make even greater sense to the English and the Dutch. Some extracts of Lisola's correspondence with the Elector of Cologne, Maximilian-Henry of Bavaria, were translated into English in 1672. The bulk of these papers related to the fate of a disputed stronghold along the Rhine called Rheinberg. The reason for Lisola's intervention was that the Elector was a protégé of Louis XIV, keen to assert his claim to Rheinberg against the Dutch. The existence of an English translation of Lisola's papers on the 'Rheinberg incident' shows that he still had a ready audience in England. ${ }^{6}$

England's position, it must be conceded, had not been the sole focus of Lisola's Buckler, but it certainly was in his tract called Traité politique sur les mouvements présents de l'Angleterre contre ses intérêts et ses maximes fondamentales (Political treatise on the present actings of England against its interest and fundamental maxims), published in the fictitious city of Villefranche in 1672, the year of the French invasion of the Dutch Republic. In this instance, no English translation was produced. Lisola essentially sought to destroy the foundation of the initially secret Anglo-French alliance of 1670-2. His fresh warning to the English fell into two principal arguments: one was the case for an English-sponsored balance of power in Europe, where the Stuarts would replicate against the Bourbons what Henry VIII and Elizabeth I had successfully achieved against Spain. England would thereby achieve the 'title' of Europe's 'fortress', as a Frankfurt-based English diplomat called it. ${ }^{6} 4$ Another argument was religious in tone, belying the idea that Lisola's writings relied exclusively on 'reason of state'. He keenly stressed that the 'interest of state' should be wedded to the 'interest of religion': England should cleave to Protestant solidarity with the

\footnotetext{
62 A free conference, pp. 33, 39, 43, 50, $5^{8}$. The treaties are of Madrid (1667) and Paris (1657).

63 Lettres et autres pièces curieuses sur les affaires du temps (Amsterdam, 1672); Letters and other curious pieces, relating to the present state of Europe (London, 1672).

64 Lisola, Traité politique (Villefranche, 1672), p. 16. Curtius to Arlington, 2o Jan. 1672: TNA, SP $81 / 59$, fo. 121 . Lisola made this argument as early as 1644 , during the siege of Gravelines, in a tract now surviving only in manuscript: 'Discours de Lisola, résident de l'Empereur à Londres, concernant l'intérêt que l'Angleterre a au sujet de Gravelines, June 1644': Paris, Bibliothèque de l'Institut, MS Godefroy 326, fos. 189-92.
} 
Dutch. Everybody knows, he now insisted, that 'religion is the soul of the state'. ${ }^{6} 5$

Lisola's Traité politique is connected to another anonymous pamphlet first published in French as La France démasquée (1670) and later translated into English as The French politician found out (1680) - a translation that included an addition where an argument was made for an invasion of Aquitaine and Normandy, a revival, no less, of England's medieval empire in France, a proposal which served as a counterpoise to Aubery's claim that Louis XIV's lineage made him eligible to the succession of the Carolingian Empire. ${ }^{66}$ There is no certainty that La France démasquée was authored by Lisola. What the sources confirm, however, is that it was believed to be by Lisola, both in London and Brussels. In the latter, the council of state was convinced it was his. ${ }^{6} 7$ That the pamphlet's publication coincided with the French invasion of Lorraine must have been interpreted as a typical Lisola move. In drawing this conclusion, the council agreed with Daniel Lindenov, Denmark's envoy to London, who also attributed La France démasquée to Lisola, emphasizing the 'powerful impression' it made on metropolitan minds. ${ }^{68}$ It took another decade for an English translation to appear, but the French original would have sufficed to carry the arguments of the Buckler a step further.

A problem bedevilling examination of Lisola's footprint is the attribution of anonymous publications. He is sometimes made responsible for England's appeal from the private cabal at Whitehall, mentioned earlier as the most celebrated assault on the Third Anglo-Dutch War. Although most likely the work of du Moulin, it has also been attributed to the English politicians Sir William Coventry and John Trevor. ${ }^{69}$ In the same year, ${ }^{1673}$, Observations on the letter written to Sir Thomas Osborn appeared: this too is attributed to Lisola, but also to Slingsby Bethel, for it defends Bethel's earlier Present interest of England stated (1671). These ambiguous attributions are testaments to the interchangeability of many of their arguments. It is more fruitful to follow Lisola's influence not through attribution, but rather through a brief examination of echoes of his ideas in the work of others, not least because English authors were able to deploy his arguments further than was possible simply by translating the Buckler.

Lisola and Bethel are bibliographically entangled. We have seen that the Free conference, added to the Buckler in 1673, popularized Lisola's themes. We do not

${ }_{5}$ Lisola, Traité politique, p. 28.

66 Lisola, The French politician found out (London, 168o), part II.

67 Council of state, 29 Sept. 1670: AGR, I $112 / 253$, unfoliated. The tract was published in The Hague by Jean Laurent, who also published Lisola's Discours touchant les prétentions de la France sur les places de Condé (1670). See E. F. Kossmann, De Boekhandel te 's-Gravenhage tot het eind van de $18^{\text {de }}$ eeuw (The Hague, 1937), p. 230.

68 Lindenov to Christian V, 9 Sept. 1670 : Waldemar Westergaard, ed., The first Triple Alliance: the letters of Christopher Lindenov, Danish envoy to London, I668-I672 (New Haven, CT, 1947), p. 298.

69 Haley, William of Orange, pp. 107-10. 
know its author, but its arguments resemble those which Bethel had made in The world's mistake in Oliver Cromwell (1668). A City merchant, former republican, and future Whig, Bethel began his pamphleteering career with this well-known attack on the Protector's foreign policy. He indicted the 'tyrant', for, like many republicans, he believed the Lord Protector betrayed rather than fulfilled the Republic, so that the epithet 'tyrant' was not merely an adoption of Restoration royalist clothing. Bethel judged that Cromwell's 1655 war against Spain was disastrous because it paved the way for French expansion, the Protector blindly following superannuated shibboleths which identified Spain as the essential enemy of Protestantism. Cromwell failed to see that 'our interest was changed from what it had been ... for eighty years [which was] to side with France against Spain, the House of Austria then being in a fair way (as they had long designed) of carrying the universal monarchy'. The terminus of Spanish power could be dated to around 1640 , the year of the defeat of the Spanish navy by the Dutch, the revolt of Portugal, and French encroachments in Catalonia. Cromwell's misguided policy rendered France 'too great for Christendom, and ... broke the balance betwixt the two crowns of Spain and France'. By 'increasing the greatness of so near a neighbour, [he] ... increased our future dangers'. And by the Treaty of the Pyrenees Louis XIV duly got 'many places in the Spanish Netherlands, and Catalonia into boot' $7^{\circ}$

Several of Bethel's later treatises are economic more than diplomatic in their analysis of the French threat, and were conjoined with admiration for the Dutch economic miracle, $7^{1}$ but two pamphlets of 1671 and 1673 , The present interest of England and Observations on the letter written to Sir Thomas Osborn, rehearse again the narrative of Spanish decline and French insurgency since 1640 , and urged the case for upholding the Triple Alliance. $7^{2}$ A significant feature of both tracts is the reiteration of Lisola's principle that the Low Countries are now to be treated as England's front line of defence. 'It can in no kind be for the safety of England to subvert Holland and Zealand, etc., which are properly called the outguards or the works against all invasions, and cannot be demolished, or in the hands of France, without laying England naked'. The Low Countries provide the 'invincible bulwark' against France. Bethel was an ardent promoter of the discourse of 'reason of state', seeking to establish an exact calculus of national interest, unclouded, he insists, by passion or ancient prejudice. Interests are historically mutable, he explains, and a

$7^{\circ}$ Slingsby Bethel, The world's mistake in Oliver Cromwell (London, 1668), pp. 3-4, 6, 10, and passim. The trans-Pyrenean provinces of Catalonia, now Roussillon, were transferred to France by the treaty.

${ }^{71}$ Slingsby Bethel, An account of the French usurpation upon the trade of England (London, 1679), and The interest of princes and states (London, 1680).

$7^{2}$ The Observations (London, 1673) critiques the duke of Buckingham's anti-Dutch Letter to Sir Thomas Osborn (London, 1672), which in turn answered Bethel's Present interest (London, $1671)$. A second edition of Observations (1689) includes a reprint of The world's mistake. 
modern understanding of England shows that commerce must now be queen of public policy; that maritime is as important as territorial power; that England must attend to the 'general balance of Europe' if French 'universal monarchy' is to be averted; and that the old enemy, Spain, is a broken reed. Bethel adds a Lisolan touch in slyly referring to Louis's propensity to send advance guards of scribbling lawyers into battle: 'his aims may be guessed at by the writings of his subjects'.73

When we turn to England's appeal we are struck by the closeness of its analysis to that of Lisola; and indeed du Moulin (if it is his) refers the reader to 'many other particulars, too long to be inserted in this short discourse, ... at large, in the incomparable book of the Baron de Assola [sic], entitled, The buckler of state, which to this day could not be answered by the French'. The Appeal accordingly asserts that the Triple Alliance is the foundation of a sane English foreign policy, which ought (the author flattering King Charles) to be 'the public institute of our Justinian'; and that, for Europe, it should stand in a diplomatic holy trinity alongside the Treaties of the Pyrenees and Aix-la-Chapelle. While identifying the origins of French aggrandizement from Henri IV onward, the crucial moment, given France's devastating internal weaknesses in the two decades before Louis XIV's accession to personal rule, was the launch of the War of Devolution. The author recounts France's profound breach of 'public faith' by its cancellation of Maria Theresa's solemn renunciation. Not only would it be hard to 'imagine stronger words, or fuller expressions' than the renunciation, but also the Treaty of the Pyrenees had explicitly declared that the reason for the renunciation was the 'troubles and afflictions' which Europe would suffer should the Bourbon and Habsburg kingdoms be 'united and joined'. The tract also reflects other leitmotifs of Lisola's and Bethel's writings: England's cardinal role as the 'balance', the folly of Cromwell's alliance with France, and the importance of the Dutch barrier.74

In the eyes of the early Whig movement in the late 1670 , the Triple Alliance came to seem like the dislodged foundation-stone of a sound foreign policy. In his Account of the growth of popery and arbitrary government (1677), Andrew Marvell opened his narrative of national folly with the Second Anglo-Dutch War, arguing that it ought to have demonstrated to Charles the perfidy of Louis XIV. The French king had dissembled in his supposed support for Charles, leaving England to suffer naval disaster. England shattered, Louis was free to launch the War of Devolution, and had in violation of all the most solemn and sacred oaths and treaties, invaded and taken a great part of the Spanish Netherlands, which had always been considered as the natural

73 Bethel, Observations, pp. 16-1 7; idem, Present interest, preface, and pp. 29, 33 .

74 Pierre du Moulin (?), England's appeal (n.p., 1673), pp. 7, 8, 10, 11. 
frontier of England'. Charles had then been momentarily jolted into sanity and had hurried to make the Triple Alliance. This was 'a thing of so good a report and so generally acceptable to the nation, as being a hook in the French nostrils', but soon enough the king undid it by his shameful Treaty of Dover.75

For Whigs, the Revolution of $1688-9$ fundamentally involved a revolution in foreign policy: an end to the Stuart appeasement of France and the permanent installation of the Habsburg-Dutch-English axis that would persist as the bedrock of English diplomacy throughout the following century. Sir William Temple now acquired a golden reputation - enhanced by the literary endeavours of Jonathan Swift $7^{6}$-as the visionary who had devised the original Triple Alliance, the diplomat who shaped the anti-French future. Naturally, the living Englishman eclipsed the dead Burgundian. Yet Lisola's Buckler remained in play in post-Revolution writing: 'the most excellent treatise of the truly honourable and learned statesman the Baron d'Isola', as the political economist Roger Coke put it in 1697; while David Jones, who touted his own service as a double agent at the French court and who exposed the perfidy of Anglo-French dealings, explicitly recommended the Buckler as a complement to Temple's Memoirs. When, in 1701, the radical Whig author John Toland discussed the 'balance of Europe' and pressed the case for embarking on the War of the Spanish Succession, he cited Lisola in support. 77

Meanwhile, Lisola had become a staple in the libraries of statesmen, merchants, and intellectuals. The Buckler appeared in a dozen auction catalogues between 1680 and 1697 , including those of the Restoration statesmen the earl of Bristol and the duke of Lauderdale..$^{8}$ John Locke owned copies, all in French, of the Bouclier (Brussels, 1667), La politique du temps (Charleville, 1671), La sauce au Verjus (Strasburg, 1674), and Raisons politiques touchant la guerre en Allemagne (Strasburg, 1675).79 Back in the early 167os, Locke's predecessor as secretary of the Council of Trade and Plantations, Benjamin Worsley, had been an early convert to a pro-Spanish foreign policy and had advised Arlington and Buckingham accordingly. His memoranda of 1669 survive in one of Locke's notebooks. ${ }^{80}$ Among other owners of copies of the Buckler

75 Annabel Patterson, Martin Dzelzainis, N. H. Keeble, and Nicholas von Maltzahn, eds., The prose works of Andrew Marvell (2 vols., New Haven, CT, 2003), II, pp. 242, 25 . At p. 276, Marvell cited Lisola's La politique du temps (1671), which rehearsed many of the arguments of the Buckler.

$7^{6}$ A. C. Elias, Swift at Moor Park (Philadelphia, PA, 1982).

77 Roger Coke, A detection of the court and state of England (London, 1697), p. 42 ; David Jones, The secret history of Whitehall (London, 1697 ), sig. A5v; John Toland, The art of governing by parties (London, 1701), pp. 142-3.

$7^{8}$ Too numerous to list and readily traceable in Early English Books Online.

79 John Harrison and Peter Laslett, The library of John Locke (Oxford, 1971), nos. 71, 402, $1763^{\mathrm{a},} 255^{6 .}$

80 Locke, '1661 notebook': Bodleian Library, Oxford: microfilm 77, pp. 18o-214; Thomas Leng, Benjamin Worsley (I6I8-1677): trade, interest, and the spirit of revolutionary England (Woodbridge, 2008), p. 161. 
were the diarist John Evelyn, the natural philosopher Robert Hooke, and the Scottish patriot Andrew Fletcher. ${ }^{81}$ The Buckler was one of two dozen books listed in the inventory of justice Peter Tilton, of Hampshire County, Massachusetts, who died in 1696 , where it stood alongside law books, biblical commentaries, Foxe's Acts and monuments, Bunyan's Pilgrim's progress, and Henry Care's Whig cyclopaedia, English liberties. ${ }^{82}$

Finally, it is no surprise to find Lisolan rhetoric fuelling the pamphleteering of the Revolution. A tract called Popish treaties not to be relied on, evidently dating from November or December 1688, because addressed to a 'friend in the Prince of Orange's camp', rehearsed the elemental matter of trust. The author repeated the familiar charge that Catholics systematically violated the sacred duty of keeping trust, a theme deeply embedded in Protestant polemic. It was said to be a doctrine of the Catholic church that 'faith need not be kept with heretics' and hence a papist's oath was inherently untrustworthy. The tract pronounced that Catholics 'are not ... tied by law, treatises, promises, oaths, or any other bonds of human society'. The supreme proof of this was Louis XIV's reneging, by the War of Devolution, on his prior solemn undertaking. The author then cited Lisola. 'The present French king renounced all his pretensions on Flanders, concluded the Pyrenean Treaty, and swore at the altar, not to meddle with the country, but how well he observed that sacred covenant, Baron d'Isola will best inform you in his Bouclier d'etat.' 83

The Buckler had thus, during the course of the Restoration, become a standard source for the understanding of contemporary geopolitics. It may therefore be one of the great cunnings of history that William III's rise to power and incarnation as a Protestant hero - a reputation which masked his cross-confessional alliances - was informed by the ideas of a Catholic diplomat and pamphleteer, born and raised in a Spanish land and faithful to his master the Holy Roman Emperor.

${ }^{81}$ Evelyn's library catalogue: BL, Add. MS $7863_{2}$, fo. 176 ; Bibliotheca Hookeriana (London, 1703 ), p. 48; J. M. Willems, ed., Bibliotheca Fletcheriana (Wassenaar, 1999), p. 130.

${ }_{82}$ Hampshire County Probate Records, $148 / 18 / 5$. With thanks to Carl Hammer for this information.

83 A third collection of papers relating to the present juncture of affairs (London, 1688), pp. 1, 4 . 